\title{
Leopard and its mythological-epic motifs in Shahnameh and four other epic works (Garshasbnameh, Kushnameh, Bahmannameh and Borzunameh)
}

\section{Leopardo y sus motivos mitológicos-épicos en Shahnameh y otras cuatro obras épicas (Garshasbnameh, Kushnameh, Bahmannameh y Borzunameh)}

\author{
Nasrin Sharifizad \\ PhD student in Persian Language and Literature (pure), Mashhad Branch, Islamic Azad \\ University, Mashhad, Iran \\ ORCID: https://orcid.org/0000-0001-7171-7103
}

\section{Mohammad Shah Badi'zadeh}

Assistant Professor, Department of Persian Language and Literature, Mashhad Branch, Islamic Azad University, Mashhad, Iran

ORCID: https://orcid.org/0000-0002-1555-3877

\section{Reza Ashrafzadeh}

Professor, Department of Persian Language and Literature, Mashhad Branch, Islamic Azad University, Mashhad, Iran ORCID: https://orcid.org/0000-0002-5392-9273

Received 02-08-20 Revised 04-10-20

*Correspondence

Email: Amirrezas610@yahoo.com
Accepted 01-11-21 On line 01-18-21

Cite as: 


\section{Summary}

In Shahnameh and other epic poems where the reflection of myths is the life of primitive and ancient Iranian communities, animals and other creatures are of great importance and go beyond their normal features and position. Myths that are the facts from the thoughts and ideas of the early man are mixed with different stories and are expressed symbolically and mysteriously. Among the animals, "leopard" is one of the role players whose name has been mentioned in Ferdowsi's Shahnameh and other epic poems and has accounted for themes and motifs. This paper seeks to examine the place of leopard in past myths and civilization as well as in the most valuable epic work, i.e. Shahnameh, and four other epic poems (Garshasbnameh, Kushnameh, Bahmannameh and Borzunameh) and extract, classify and analyze the most important mythological-epic and ritual motifs of this animal. These motifs include the lexical and symbolic meaning of leopard, the position of leopard in the myths and civilization of ancient Iran, the relationship between the goddesses and the leopard, the characteristics of leopard, child and leopard, leopard skin as a garment, metamorphosis, leopard in the welcome ceremony, leopard skin as a gift, demonic creature, leopard totem, leopard as war booty, leopard in the treasure of kings and leopard spell. The concept or symbol of the leopard in this research relies on its positive aspect, sometimes it is one of the goddesses and is respected and sometimes it is a symbol of courage, strength and victory.

Keywords: Leopard, Shahnameh, mythological-epic motifs, epic poems

\section{Resumen}

En Shahnameh y otros poemas épicos donde el reflejo de los mitos es la vida de las comunidades iraníes primitivas y antiguas, los animales y otras criaturas son de gran importancia y van más allá de sus características y posición normales. Los mitos que son los hechos de los pensamientos e ideas del hombre primitivo se mezclan con diferentes historias y se expresan simbólica y misteriosamente. Entre los animales, el "leopardo" es uno de los actores cuyo nombre se ha mencionado en el Shahnameh de Ferdowsi y otros poemas épicos y ha explicado temas y motivos. Este artículo busca examinar el lugar del leopardo en los mitos y la civilización del pasado, así como en la obra épica más valiosa, es decir, Shahnameh, y otros cuatro poemas épicos (Garshasbnameh, Kushnameh, Bahmannameh y Borzunameh) y extraer, clasificar y analizar los más importantes. motivos mitológico-épicos y rituales de este animal. Estos motivos incluyen el significado léxico y simbólico del leopardo, la posición del leopardo en los mitos y la civilización del antiguo Irán, la relación entre las diosas y el leopardo, las características del leopardo, el niño y el leopardo, la piel de leopardo como prenda, la metamorfosis, leopardo en la ceremonia de bienvenida, piel de leopardo como regalo, criatura demoníaca, tótem de leopardo, leopardo como botín de guerra, leopardo en el tesoro de los reyes y hechizo de leopardo. El concepto o símbolo del leopardo en esta investigación se basa en su aspecto positivo, a veces es una de las diosas y es respetado y a veces es símbolo de valentía, fuerza y victoria.

Palabras clave: leopardo, Shahnameh, motivos mitológicos-épicos, poemas épicos

\section{Introduction}

In epic stories, creatures and animals play a role as heroes. Among mythological animals, the value and importance of leopard in human life is such that ritual and belief narratives have been produced about it. Some of these narratives indicate the strong presence of this animal in human life and some other have changed in nature by merging into a legend or story and have found a mythical, symbolic and mythological appearance. The most prominent references to this animal 
can be seen in epic works such as Shahnameh, Garshasbnameh, Kushnameh, Bahmannameh and Borzunameh. Further, a brief description of these five epic works has been provided in this article.

\section{Statement of the problem}

Ancient texts are one of the most important sources for understanding the value of animals in the ancient Iranian culture and undoubtedly, in order to understand the importance of animals, the repetition of their names in ancient texts or depiction of their image in works of art can be used. In this way, these texts talk about the importance of animals and how to deal with them in ancient Iran and Iranians could use the physical and behavioral characteristics of animals to express their beliefs and give their ideas a symbolic color. Among mythological animals, "leopard" has not always been considered a demonic creature. Evidence left from ancient Iran suggests the special place of leopard in the minds and culture of the people of that time. Sometimes, leopard has always received considerable attention as a symbol of power and courage (likening of brave warriors to leopards) and the use of mythological-epic and ritual names, themes and motifs of this animal in poems such as Ferdowsi's Shahnameh, Garshasbnameh, Kushnameh, Bahmannameh and Borzunameh confirms this issue. Comparisons and metaphors about the leopard in these poems have been further based on the power, aggression and courage of this animal. In this article, attempt has been made to extract various motifs about the leopard by studying Shahnameh and other epic poems and considering folk narratives (Seddiqiyan, 1996:74).

\section{Research literature review}

Concerning the leopard and its role in myth and given the features that we have mentioned for it, a comprehensive study that examines the mythological-epic and ritual motifs in epic poems such as Shahnameh, Garshasbnameh, Kushnameh, Bahmannameh and Borzunameh has not been conducted. In this regard, we come across books, theses and articles. In the article "Leopard in the mythological beliefs of Semnan Province", the authors have tried to examine this animal as a goddess in folk legends (Parvar and Shahmirzad). Among the books applied in this research are "Mythological-epic culture of Iran" by Mahin Dokht Seddiqiyan, "Illustrated dictionary of symbols in Eastern and Western art" by James Hall, "Iranian mythology culture" and "The mythological encyclopedia of animals" by Khosrow Qolizadeh, "Book of symbols" (Vol. 1) by Jobs Gertrude, etc. The main research question is as follows: What is the place of leopard in the ancient and mythological past and in the mentioned epic poems from the mythological, epic and ritual dimensions?

\section{Methodology}

The present study is a descriptive-analytical research and data has been collected through documentary and library methods. The information on the subject has been gathered by referring to books, articles and websites.

\section{Results}

This research has three hypotheses which are:

1. In epic poems, probably every animal such as a leopard has special mythological functions. 2This leopard animal is involved in the national hero epics in the test of heroes. 3. In these epics, leopards sometimes reflect cultural and national commonalities between Iranian ethnic groups and other nations. Based on these hypotheses, the author has studied and taken notes on the Shahnameh and four epic poems: Garshasbnameh, Koushnameh, Bahmannameh and Borzonameh. These results were obtained: According to these hypotheses, the leopard has been totemized and embodied, and many mythical, epic and ritual themes have been formed from it. And it became clear from these hypotheses that the heroes have fought against some animals many times, including leopards, and these battles are in fact a kind of test to prove the heroism of Yalan, and sometimes the cultural commonality between the Iranian tribes and other nations is confirmed.

\section{Shahnameh}

Shahnameh, written by Hakim Abolqasem Ferdowsi Tusi, is a poetic epic in eliminated convergent poetical meter of 8 feet, which contains 60,000 verses and is one of the greatest and 
most prominent epic works in the world and took nearly thirty-five years to compose. The content of this literary masterpiece includes the myths, legends and history of Iran from the beginning until the conquest of Iran by the Arabs in the seventh century, summarized in the four dynasties of Pishdadian, Kayanian, Parthian and Sasanian kingdoms and divided into three mythological, heroic (epic) and historical parts. When the language of knowledge and literature in Iran was Arabic, Ferdowsi revived the Persian language by composing Shahnameh. One of the important sources that Ferdowsi used to compose Shahnameh was Abu Mansouri's Shahnameh (Safa, 2008: 183\&184).

\section{Garshasbnameh}

"The second great epic work (after Shahnameh) is Garshasbnameh [by Abu Nasr Ali ibn Ahmad] of Asadi Tusi, the great Iranian poet of the fifth century AH" (Safa, 2008: 283). This poem is the story of Garshasb, the great hero of Sistan and the great ancestor of Rostam; Garshasb is an Indian and Iranian mythological figure whose name and the oldest scattered news about his functions have appeared both in the Avesta letter and in the epic poems of ancient India (Sarkarati, 2008: 251). Asadi Tusi first addresses Garshasb's genealogy and after mentioning some of the events of his fathers' time, he recounts the epic narratives of Garshasb story and adorns his whole life with amazing and extraordinary events and adventures. This epic work is replete with extraordinary issues about Garshasb and of course animals play a significant role in this poem (Safa, 2008: 284).

\section{Kushnameh}

The poem of Kushnameh is among the national, mythological and heroic epics composed by Hakim Iranshah ibn Abi al-Khair in the sixth century AH. This book is the story of Kush the Tusked, Zahak's nephew, who ruled China, Morocco and Africa with power and oppression for many years, during which he was always at war with Jamshidian. But in the end, he pursues the path of justice and godliness. This book contains a description of the characteristics of a number of mythical characters. The poet of Kushnameh, Hakim Iranshah ibn Abi al-Khair, has composed it between the years 498 to $501 \mathrm{AH}$. Although the stories of Kushnameh and Ferdowsi's Shahnameh are generally similar, we find with a deeper look that the composer has not written these events by imitating the events of Shahnameh, but has benefited from authentic written and oral sources just like Ferdowsi (Safa, 2008: 298 \& 299).

\section{Bahmannameh}

It is an epic Mathnavi about the events of the reign of Bahman, the son of Esfandiar, the Kiani king, and his battles with the family of Zal's Rostam. This work contains ten thousand verses written by Iranshah ibn Abi al-Khair in the late fifth or early sixth century (Afshari, 1997, Vol. 4, Bahmannameh entry). With the reign of Bahman, Rostam's family was destroyed. In his story, myth and reality are mixed. His other name is written Ardeshir in Shahnameh and historical sources and historians have sometimes identified him with Achaemenid Cyrus and most often with Achaemenid Ardeshir (Pirniya, 2007: 884). The exact date of Bahmannameh is not clear and researchers have stated that it has been versified in the fifth century, late fifth century or early sixth century.

\section{Borzunameh}

Borzunameh is a great epic poem written by Shamsuddin Mohammad Koosaj, an eighth-century poet, in which the story of Borzu (Sohrab's son) and his wars and performances has been expressed in 4200 verses. Borzu is the son of Sohrab and lived with his mother, Shahru, in the mountainous region of Shengan. Afrasiab passes through Shengan with his army, which was defeated by Iran and was returning to Turan, and sees Borzu as a strong and worthy young man and encourages him to fight Rostam by making many promises. (Safa, 2008: 303) Borzu accepts this suggestion and leaves for Iran with the Turan corps after learning the customs of war and unknowingly confronts his ancestor, Rostam, and is eventually captured by Faramarz during several battles. Borzu is sent to Sistan fortress. After hearing the news of her son's captivity, Shahru goes to Sistan and there, with the help of a bard, she prepares the ground for Borzu's escape from the fortress. Rostam who is returning to Iran when Borzu is escaping sees him on the way and the battle between them resumes. In this battle, Borzu is defeated and his identity is 
revealed to Rostam, and the war leads to peace and friendship.(Safa, 2008: 304-306)

\section{Lexical meaning and root of the leopard}

In the Pahlavi language, the word leopard is pronounced like today's Persian pronunciation. Leopard (Palang in Persian in the same paradigm as that of Khadang) is a famous animal and anything in which the dots are of a different color. The word leopard is derived from the Avestan root meaning to fight, and the word battle is derived from this root (Abdollahi, 2002: 215). Leopard is a mammal and is categorized among carnivores and felines. The skin of this animal has black spots and is of various types (Moein, 2007, "Leopard").

\section{Leopard in Primal Creation}

According to Primal Creation (p. 100), leopards, like lions and tigers and other harmful predators, are from the order of wolves, which are called mountain gallopers. Thus, it is a demonic creature and it was a very good thing to kill them. Concerning the pious deed of killing lions, wolves and leopards, it has been narrated that "if someone kills a lion or a wolf or a leopard and every other predator, whatever sin he has committed or commits afterwards is no longer considered and the good deed is accepted from someone who kills one of those predators (Qolizadeh, 2013: 89).

\section{Symbolic meaning of leopard}

Secrecy, victory, agility, speed, lightness, courage, cunning, theft, carnivore and anyone who hits suddenly are some of the leopard's symbolic meanings. Leopard is a mysterious animal and this feature is intensified by its isolated and lonely life (Hodder, 2006: 11). In various civilizations, this animal has adopted concepts such as predation, recklessness, bravery, speed, hypocrisy and sexual power (Cirlot, 2002: 181).

In the ancient world, "leopard" is a symbol of power, and this symbol is present in many legends. Leopards were a symbol of power, violence, courage and independence of action and people who chose this symbol for themselves believed that, like the leopard which lives alone and at the same time dominates its surroundings, they also can powerfully do everything without the need for others. It also symbolizes someone who hits unexpectedly. This animal is similar to the eyeball due to the spots on its body and is considered a symbol of the god of gods, guardian and watchman. In legends, it is the predatory animal from which the mythical hero is born. Hence, it is also a symbol of returning to life (Gertrude, 1991: 31).

\section{Leopard in ancient myths and texts}

Leopards have not always been considered demonic animals. The image of a leopard is engraved on many pottery containers found in Iran. An example of these containers with the image of a leopard on them has been obtained from Silk Hill. A black stone statue of a sitting leopard has been found in Persepolis, showing the Achaemenids' respect for this animal. In the following, In Sassanid metalworking art on a copper tray, we see a scene where the king is hunting a leopard. Certainly, this scene is somehow the repetition of the motif of lion-hunting by the Achaemenid king (Qolizadeh, 2013: 89).

In the field of Jiroft civilization, the like of which has not been discovered in any of the world's ancient sites, the most important themes reflected on Halil Rud culture soapstone dishes are the scenes of the battle of felines such as lions and leopards with giant snakes or the battle of lions and leopards with stout humped cows. In ancient Iranian stories, it is said that "leopard is a very proud animal that stands on the highest possible place on moonlit nights until the moon arrives. But when it sees the moon above itself, it jumps and grabs at the sky such that it is thrown from the height and dies." (Gertrude, 1991: 230).

Chinese people believe that leopard as the representative of "Chi" and one of the four powerful animals represents the wild warrior. The animal, in the worship ceremony of Moghan and the astronomers of the time of Christ, is a sign of the necessary return of Jesus to save mankind from sin and in Greece, it is the sacred animal of Dionysus (Gertrude, 1991: 231). Leopard is also a predatory animal that can be considered a symbol of the royal and warlike class (Chevalier \& Gerberan, 1999: 236, 237). According to the ancients, dreaming a leopard means 
an oppressive king or an obvious enemy with power. If someone kills it, he kills an enemy with these features. Marriage to a leopard is the dominance over a woman from an oppressive people. From the mythological point of view, "leopard" has a secondary and complex meaning. In mythology, leopard is a symbol of female power on earth and is a sign of power both constructive and destructive and extremely scary and very lovable. There are also some words about the leopard's relationship with goddesses. (Chevalier \& Gerberan, 1999: 237).

\section{Goddesses and leopard}

In mythology and ancient motifs, images and symbols have been used to explain the forces and characteristics of gods and supernatural beings. The goddesses have been also depicted along with the symbols of animals, plants and objects. "Among them, one can refer to animal symbols such as lions, leopards, snakes, fish, goats, cows, rams, birds, and so on" (Rafi'far \& Malek, 2013: 17). These symbols are sometimes the substitutes for the goddesses and sometimes are their companions. Therefore, it is clear that there was a close relationship between the goddesses and the leopard, and this is confirmed by archaeological and mythological research. This animal has been sometimes depicted as a symbol to illustrate the power and dignity of the goddesses and sometimes as a symbol of support and companionship in the role of a guardian next to them. The goddesses are also associated with water and thus, it may be stated that the connection between the leopard code and goddesses can also be based on the connection of the goddess with water. "Numerous images of felines have been engraved on ancient human artifacts, including in Iran where we see pictures of felines. An example of them is the image of a leopard urinating, along with symbols of water and rain, and it probably indicates the relation of these symbols with each other." (Rafi'far \& Malek ,2013: 13).

The leopard's spots, which appear on the surface of its skin like eyes, are also considered a symbol of alertness and guardianship in this animal. The spots can be related to the goddesses from two perspectives:

In the first perspective, the leopard is a symbol of the goddess and the illustrator of the feminine and vigilant person that dominates various aspects of life and exerts power and controls the elements of nature and uses them to improve livelihood. (Mokhtarian, 2014: 133). Feminine affection and also a protective force can be seen in it and all the features together turn the leopard into a figure protecting people's lives.

From another perspective, the leopard skin spots represent the eye and are subsequently associated with certain sharpness that is the main and inseparable feature of a guardian and this guardian is always by the side of the goddesses, and understanding this protection on both sides is smart (Mokhtarian, 2014: 133).

\section{The most important references and motifs about leopard in epic poems}

(Shahnameh, Garshasbnameh, Kushnameh, Bahmannameh and Borzunameh)

The following are the most important themes and motifs about the leopard in epic poems and narratives:

\section{Leopard features \\ Corps}

There is no description of leopard's appearance in epic poems. The only reference is made to the presence of this animal among Houshang's corps for Siamak's blood feud:

The fairy and leopard and demon came together,

And from predators, the brave wolf and tiger were gathered,

There was an army of predatory and domestic animals and chickens and fairies,

And their commander was arrogant and heroic.

(Ferdowsi, 2007: 24)

In the story of Iraj's blood feud, the leopard and the lion are again placed in Manouchehr's corps:

The great and important people lined up in two ways,

And were all covered in gold from head to toe,

In one group, the lion and the leopard were tied, 
And in another group, huge war elephants were fastened.

(Ferdowsi, 2007: 130).

\section{Child and leopard}

One of the remarkable motifs in mythological stories about some kings and heroes is the type of their upbringing and feeding in childhood. Instead of breastfeeding, these babies are fed and raised by the milk of animals such as "leopard", "lion", "cow", "wolf", and so on. It seems that this type of upbringing affects the mood of children and when they grow up, they assume the characteristic of that animal. The motifs of nurturing with the help of lions and leopards can be seen in Shahnameh and Kushnameh. In Shahnameh, there is a verse that ironically refers to breastfeeding by a leopard:

Someone who has not been breastfed by leopards,

Would help us in this suffering and hardship.

(Ferdowsi, 2007: 81).

In Kushnameh, Nimrod's breastfeeding by a leopard has been mentioned:

I read this story in a different way,

From the words of that true-hearted and sincere man,

Since the Creator of the world took care of that infant,

He sent him a leopard,

To feed him day and night,

Sometimes by leopard milk and sometimes by game meat.

(Iranshah ibn Abi al-Khair, 1998: 498).

In narratives, the breastfeeding of Nimrod and Zahak by a leopard has also been mentioned. It is said that Zahak is the same as Nimrod.

He is called Zahak because he laughed when he was born to his mother and she put him in a waterless and grassless desert and since this was his fate, a leopard breastfed him. Some have also said that his mother's breast was cut off and she raised Nimrod with leopard milk (Seddiqiyan, 1996: 187). In Ajaib al-Makhluqat (The Wonders of Creation), it is said: In the past, a king had a maid who committed adultery and gave birth to a child. The woman took the child to the desert out of fear of the king. A female leopard came and breastfed him until he grew up. After the king was informed, the child was brought and named Nimrod. In his adulthood, Nimrod killed the king and took over the world. He was the one who intended to go to heaven and threw Ebrahim into the fire (Tusi, 2003: 578).

\section{Leopard skin as a garment}

In Shahnameh, cover and clothing have been mentioned from the very beginning. According to Ferdowsi, Kiumars was the first to choose leopard skin for himself and those around him. He also used this clothing as the war garment because it was not customary to wear caftan at that time:

It was said that Kiumars made widespread the custom and tradition of kingdom,

And he was the king himself,

When he became king of the world,

His first job was to build a place on the mountain,

His reign and fortune began in the mountain,

$\mathrm{He}$ and his group wore leopard skin clothing.

(Ferdowsi, 2007: 21).

He wore a garment made of leopard leather,

While in those days, there was neither war clothing nor war ritual.

(Ferdowsi, 2007: 23).

We read the following about Kiumars' leopard skin clothing in the comprehensive scroll of narrators: It is said that in the time of Kiumars, people wore the skin of tigers, lions and leopards. In a story, Kiumars has been considered to be the fourth son of Prophet Sheith, who is being taken to a cave on top of a mountain. Then, he is placed on a rock and is made to wear 
leopard skin and place a hat made of lion skin on his head and animals including tigers, lions and leopards are put under his command (Afshari \& Madayeni, 1998: 1).

In epic poems, Kiumars is not the only person wearing leopard skin clothing. Izad (god) Soroush also appeared in the form of a fairy wearing leopard skin garment when he came to Kiumars to inform him of the conspiracy of the demons:

One after another came the good angels,

Like a fairy wearing leopard skin clothing.

(Ferdowsi, 2007: 23).

Many epic heroes also wore leopard skin garment (Palangineh) during the war, and Rostam is at the forefront of these heroes. It has been previously mentioned that Rostam's war garment was sometimes called Babr-e Bayan (armor made of tiger skin) and sometimes Palangineh. The cover of heroes' horse or their hat is sometimes leopard skin:

This guardian of the plain went to him shouting,

While he was holding his hand to his bleeding ears,

He told him: He was a man like a black demon,

Who was wearing leopard skin clothing and an iron hat,

The whole plain is full of demons,

Or is like a dragon asleep in a war suit.

(Ferdowsi, 2007: 33).

When he enters the war, he wears a war suit,

And another person fastens its strap,

Another one has a leopard skin garment,

And wears it and enters the war,

It is called Babr-e Bayan,

Which is considered something more than a war suit.

(Ferdowsi, 2007: 187-188).

Ever since Giv left Iran,

How hard he stayed in Turan,

He slept on soil and rocks,

His food was game meat and his garment was leopard skin.

(Ferdowsi, 2007: 105).

I heard that the brave Shangaveh,

Used a big stone as his weapon,

One whose garment was made of leopard leather,

And he wore it and entered the war.

(Ferdowsi, 2007: 645).

In Shahnameh, as mentioned, Rostam's garment is made of leopard skin and Giv wears such a garment on his trip to Turkestan to find Kay Khosrow, and Shangaveh's clothing is also made of leopard skin.

In Garshasbnameh, Sarand, the son of the king of Kabul, likens Turak to a demon and his horse to a dragon wearing a leopard skin garment:

Sarand, from one side, saw an angry demon,

Who wore a garment made of leopard skin.

(Asadi Tusi, 2003: 67).

The people in the army that Garshasb brings with him to Zahak from Zawol in order to be sent to help Mehraj are slaughtered by Kenarang, and their war garments are made of leopard skin:

He prepared a beautiful army like a mountain,

From the spearmen of the first group,

He gave them ropes and bows from the tools of war,

And they wore war clothes beneath plus a garment made of leopard skin.

(Asadi tusi, 2003: 86).

The heroes dressed in leopard skin, out of hatred and enmity,

First suddenly opened the way by waiting in ambush.

(Asadi tusi,2003 : 102).

In the fight against Garshasb, the army of King Laqateh is wearing leopard skin: 
They went through three stages of the war and came forward,

Roaring with countless armies and ready for war,

Their helmets were made of fish teeth,

And their war garment made of leopard skin.

(Asadi tusi,2003: 67).

They held shields made of whale leather,

And wore clothes made of leopard skin.

(Asadi tusi,2003: 267).

The war garment of Metoz, the hero of King Tanjeh's corps, is also made leopard skin:

His flag was made of whale skin and his war clothes made of leopard skin,

And he had a black horse and a red war garment.

(Asadi tusi, 2003: 387).

According to the quoted evidence, the theme of wearing leopard skin clothing by the heroes and demons has been mentioned in Shahnameh and Garshasbnameh. Apart from this, horse cover and saddle and sometimes the spear were made of leopard skin. In epic poems, the saddle (made of leopard skin) has been mentioned several times. Since there is a lot of evidence in this regard, a few verses from Shahnameh are mentioned as an example:

He grabbed his belt,

And removed him from the leopard skin-made saddle.

(Ferdowsi, 2007: 348).

He removed me from the leopard skin-made saddle,

Such that it is as if I do not weigh even as much as a mosquito.

(Ferdowsi, 2007: 349).

He ordered a royal silk fabric,

To be spread over the young boy,

The same colorful silk cover,

The same royal bed and precious leopard skin-made saddle,

Were set on fire and screams were let out,

He said: Weep, O young king!

(Ferdowsi,2007: 433).

In addition to the epic poems of Iran, the theme of leopard skin clothing is sometimes seen in the culture of other nations. Egyptian priests, for example, wore leopard skins during funerals and showed the deceased in the same way and it seems that this was considered a means of his survival after death. In China, the uniforms of some officers were decorated with leopard skin to symbolize bravery in war (Hall, 2001: 40).

\section{Leopard as a demonic creature}

As to the leopard, it has been said that, like other predators, it belongs to the group of wolf-like animals and is a demonic creature. So, it is good to kill it. In Shahnameh, it sometimes has a demonic face with characteristics such as sharp claws, roaring and malevolence (Qolizadeh, 2008: 154).

\section{Leopard totem ${ }^{1}$ (connection between the leopard and people's names and its image on flags)}

Although the leopard is sometimes called a demonic creature, its traces can be seen in the totem of some heroes. In past times, the image of various animals on the flag of heroes and families signaled the special totem of that family or those individuals. The leopard is one of the animals that plays the role of heroes' flag in the epic poems. During the Achaemenid and Sassanid eras, the Iranian national and military flag, which was known as the Kaviani flag and caused victory in the battle against the enemies, was made of leopard skin. (Mas'oudi, 1977: 213). The body of animals on military flags depended on their military makeup so that on the flags that were in the heart of the corps, the image of large predators such as dragons and elephants was displayed and smaller predators such as lions, leopards and boars appeared on the right and left side flags and the flags of the flanks also had the image of smaller predators such as wolves on them (Mas'oudi, 1977: 213). 
Moreover, it is said that the bodies of animals such as dragons, lions, leopards, wolves, etc. were made of cloth or leather. As the bodies were lifted, they were filled with air from the mouth depending on the rhythm of the flag-bearer's movement, running, taking quick steps as well as the wind blowing towards the friendly forces and they made a sound like the sound of a predator, which caused fear and anxiety in the enemy's army (Bakhturtash, 2004: 117).

In the collection of epic poems in Shahnameh and Bahmannameh, this image can be seen on the flag of Ashkash, Pashutan_ Esfandiar's army commander_ and Shiran_Bahman's major general:

The clever Ashkash went behind Gostham,

Who was strong and brave and smart,

He was one of the mace-bearer and of Homay race,

He withstood in the way he was asked,

And prepared an army of Kuch and Baluch heroes,

Who was thinking of war,

No one in the world had seen a race like them,

They were always wearing war clothes and not a single finger of them was bare,

They raised a flag that resembled the body of a leopard,

And from this flag came the smell of war.

(Ferdowsi, 2007: 21).

He saw an army with war clothes and war tools,

And a black flag on which the image of a leopard's body was depicted,

The commander of the corps, Pashutan, was in the heart of the army,

An army that was ready to die.

(Ferdowsi, 2007: 269).

After him, like the lions of the famous sun,

His race was from Khorasan,

The flag behind him was like a silk fabric with the image of a leopard,

His army was all united and brave.

(Iranshah ibn Abi al-Khair, 1991: 193).

\section{Metamorphosis into the leopard's face}

Metamorphosis means the transformation of appearance and structure and the basis and legitimate identity of a person or object using supernatural force, which seems unusual at any time and period. In this state, the person or object changes from one form to another and finds a new body whose occurrence may be formal, apparent or tangible, or they may undergo fundamental changes in nature and gain new powers that they did not have before and thus, although in principle, they are the same as before, a new transformation has taken place in their exterior and interior, as a result of which they have taken on a new form and special and different actions (Rastegar Fasaei, 2004: 43-44). Leopard is one of the animals about which the motif of metamorphosis has been expressed in the epic poems of Shahnameh and Garshasbnameh. In Shahnameh, Kay Khosrow crosses the sea after the battle with the King of Makran and sees wonders in the sea, like animals with the body of fish and the head of a leopard:

With forgiveness and chivalry, he was led to a path,

Where he was called the captain of a dangerous place in the sea,

The army was surprised by that water,

Everyone pointed to the king with their fingers,

They saw one whose body was like a fish and whose head like a leopard,

And another one with the body of a zebra and the head of a whale.

(Ferdowsi, 2007: 297-298).

In the battle of the Hetiyal Corps, the Chinese Khaqan Corps, the face of the Khaqan Corps has been described as a demon and their claws as a leopard's claw:

One told the other,

I have never seen a war like this going so slowly,

Indeed, that corps was all human, 
It is not worth looking at them,

In the interior, they all looked like demons and predators,

And in the exterior, they seemed to be far from good and bad thoughts,

From small and large spears and maces and swords,

It was as if they had no escape,

Their claws were like leopards,

It seemed they were not fed up with fighting and kept going.

(Ferdowsi, 2007: 240).

In addition to the epic poems of Iran, in Egyptian mythology, there was a goddess (Mafdat) who was called the destroyer of snakes and scorpions and had the shape of a leopard (Hall, 2001: 40).

\section{Leopard in the welcome ceremony}

The motif of using animals such as leopards in the welcome ceremony is a theme expressed once in the epic poems in Garshasbnameh, and it is in the welcome ceremony of Fereydoun for Nariman:

The leopards were fastened with gold chains,

The angry wolf and lion were captured by a rope,

Amol became like a paradise that had just been decorated,

And money was thrown under the feet and it was like a silk fabric.

(Asadi Tusi, 2003: 369).

\section{Leopard skin as a gift}

Offering the skin of animals is a theme that is sometimes seen in epic poems. Leopard skin and what was made of it, such as horse instruments and tent, are among these gifts. This function has been mentioned in Shahnameh, Borzunameh and Garshasbnameh:

The leopard you call a barbarian,

Is more valuable and important than those four hundred skins.

(Ferdowsi, 2007: 71).

He told the treasurer guardian to give a bag of gold,

And that crown and the gold and precious bracelet,

From that golden bridle and the bone made of white poplar,

Long metal ring and leopard bone,

The treasure guardian quickly brought to the king of the Turks and the young man.

(Koosaj, 2008: 8).

Great men and kings of the Orient,

For other masters and great men,

Prepared gifts separately,

And gave them from the treasure,

They put thousand pieces of colorful silk fabric,

And a hundred leopard skins on camels' back.

(Asadi Tusi, 2003: 273).

Forty simple tents made of leopard leather,

And colorful silk fabrics,

He took to Nariman the hero,

He praised kindly and thanked and accepted.

(Asadi tusi,2003: 340).

Colorful silk tents,

Inside them was the image of a leopard.

(Ferdowsi, 2007: 127).

It seems that these tents were either made of leopard skin or had designs like leopard skin.

\section{War booty}

Leopard is an animal whose skin has been very valuable. In Garshasbnameh, it is found among the lyrics that Garshasb obtains from the treasure of the King of China: 
Booties like four hundred Chinese paper bags,

Sword handles made of leopard skin leather.

(Asadi Tusi, 2003: 365).

\section{Leopard in the treasure of kings}

One of the references made to leopard is the presence of this animal in the treasure of kings. Among the epic poems in the historical period of Shahnameh, there is a reference to the presence of leopard in the king's treasure:

His wealth and possessions were so great that there was no end to it,

There was no such a man of tall stature like him in the world,

Falcon, hawk and eagle,

Lion, leopard and whale in the water he had them all.

(Ferdowsi, 2007: 296).

\section{Leopard spell}

In mythology, animals were sometimes used as spells. The horse spell guarded the crypts so that they would not be harmed. Leopards have also been used as a spell in folk narratives. According to narratives, Fereydoun's cave had a spell in which Borzu was trapped, and the king of the jinns told Borzu the way to free himself from this spell. Among the spells is the presence of a minaret on top of the mountain where a demon is sitting and his horns have come out of the skull. Borzu should soften it with a vertical and remove it. By removing it, oil is found and a leopard with a spell tablet on its chest appears. Borzu should hit the leopard's head with a sword so that his chest becomes open and the spell tablet appears (Afshari \& Madayeni, 1998: 374). Jahanbakhsh, Faramarz's son, also encounters Fereydoun's spell of Turban in his sixth Khan, where the spell tablet is in a leopard's chest (Afshari \& Madayeni, 1998: 417). In Garshasbnameh, there is a mention of a stone which seems to be like a spell. If someone ties it to his waist, he will not be harmed by the leopard:

There was a black and white stone,

From each stone appeared the image of a leopard,

If each stone was broken into one hundred thousand pieces of stone,

All had an image of a leopard on them,

Anyone who tied one of them to his body,

Was no longer harmed by the angry leopard.

(Asadi Tusi, 2003: 274).

\section{Discussion}

The variety of themes and subjects in Persian literature makes the necessity of familiarity with different branches of literature inevitable. The long history of epic literature in poetic and prose literature has long been considered. In these epic poems, in addition to humans, animals are also included. These stories are inseparable and play a significant role.

Among the poems of Persian literature, research has been done on Shahnameh, this masterpiece in the field of Persian literature, and several other epic works; But so far, no research has been done on the role of leopards and the epic-mythological themes of animals in Shahnameh, Garshasbnameh, Koushnameh, Bahmannameh and Borznameh. I decided to study the role and position of animals in terms of myth and epic theme. This research can also provide a basis for new research.

\section{Conclusion}

From what has been stated in this study, it is concluded that leopards have not always been considered demonic creatures in mythology. Evidence left from ancient Iran shows the special place of leopards in the minds and cultures of the people of that time and sometimes this animal was one of the goddesses respected by people. Sometimes in the mentioned epic poems, we come across the metamorphosis of this animal, and sometimes the leopard or its head has been used as a spell. Leopard skin was valuable and was sometimes sent as spoils of war and sometimes as a gift and on some occasions, it was a trace in the totem of some heroes and its 
image on the Iranian national and military flag has been the cause of victory against the enemy. Leopard has always been considered as a symbol of power and courage and the use of various mythological, epic and ritual names, themes and motifs of the leopard in Ferdowsi's Shahnameh, Garshasbnameh, Kushnameh, Bahmannameh and Borzunameh (likening of warriors to leopards) confirms this issue. Comparisons and metaphors about leopards are more based on this animal's power, aggression and courage.

\section{Endnote}

(1) In general, totem is an edible and harmless animal or a dangerous and scary animal that has a special relationship with the people in a group and a plant or one of the natural forces (rain, water) is rarely placed as totem. Totem, in the first place, is the forefather of the group and secondly, it is a guardian and benevolent spirit sending a message through the unseen voice and while it is dangerous to others, it recognizes its children and does not harm them. There are different types of totems: A) Tribal totem that passes down from generation to generation; B) gender totem, i.e. a totem belonging to all members of the tribe who are of the same sex, male or female, and other members of the tribe who are of another sex do not share in this totem; C) personal totem which belongs to a person and is passed on to his descendants (Freud, 1970: 141).

Totemism is a matter related to primitive human history. But one cannot certainly say that all primitive tribes believed in totems: "Animals and plants did not appear only in the role of tribal totem; perhaps single people who recognized an animal or plant origin for themselves were the people from tribes and families who did not have a totem" (Bahar, 2002: 490).

\section{References}

Abdollahi, M. (2002). A dictionary of animals in Persian Literature. Vol. 2, Tehran: Pazhuhandeh.

Afshari, M. (1997). Bahmannameh. Entry of the Encyclopedia of the Islamic World, Vol. 4. Tehran: Encyclopedia of the Islamic World Foundation Publications.

Afshari, M. \& Madayeni, M. (1998). Haft Lashkar (Seven Army) (comprehensive scroll of narrators). Tehran: Research Institute of Humanities and Cultural Studies.

Anousheh, H. (1997). Dictionary of Persian Literature (Encyclopedia of Persian Literature 2). Tehran: Printing Organization in Publications.

Asadi Tusi, A. (2003). Garshasbnameh. With the efforts and correction of H. Yaghmaei and edition by P. Yaghmaei. Tehran: Donyaye Ketab.

Bahar, M. (2002). From Myth to History. Tehran: Cheshmeh.

Bakhturtash, N. (2004). Flag of ancient Iran to this day (History of the Iranian flag). Tehran: Behjat.

Chevalier, J. \& Gerberan, A. (2009). Dictionary of symbols (5 volumes). Translated by S. Fazayeli. Tehran: Jeyhun.

Cirlot, Y, E. (2002). A dictionary of symbols.forward by Herbert Read, second edition ,Routledge . London.

Ferdowsi, A. (2007). Shahnameh (8 volumes). With the effort of J. Khaleqi Motlaq. Tehran: Great Islamic Encyclopedia Center.

Freud, S. (1970). Future psychoanalysis of an idea. Translation of annotation and introduction by H. Razi. Tehran: Kaveh.

Gertrude, J. (1991). Symbols (The First Book of Animals). Translated by M. R. Baqapour. Tehran: Akhtaran Publishing.

Hall, J. (2001). Illustrated dictionary of symbols in Eastern and Western art. Translated by R. Behzadi. Tehran: Farhang-e Mo'aser.

Hamidian, S. (2004). Sa'di in ode. Tehran: Qatreh.

Iranshah ibn Abi al-Khair (1991). Bahmannameh. Edited by R. Afifi. Tehran: Scientific and Cultural Center.

Iranshah ibn Abi al-Khair (1998). Kushnameh. With the effort of J. Matini. Tehran: Scientific and Cultural Center. 
Koosaj, Sh. M. (2008). Borzunameh [ancient section]. Introduction, research and correction by A. Nahvi. Tehran: Mirase Maktoob.

Mas'oudi, A. (1977). Murūj al-Dhahab wa Ma'ādin al-Jawher. Translated by A. Payandeh, Vol. 1. Tehran: Book Translation and Publishing Company.

Moein, M. (2007). Moein Dictionary (6 volumes). Tehran: Amir Kabir.

Mokhtarian, B. (2014). Babr-e Bayan and Anahita's Bawri Dress. Literary studies, Ferdowsi University of Mashhad, No. 186, pp. 123-144.

Pirniya, H. (2007). Ancient Iran. Tehran: Narmak.

Qolizadeh, Kh. (2008). Iranian mythology culture based on Pahlavi texts. Tehran: Parse Publications.

Rafi'far, J. \& Malek, M. (2013). Iconography of the sign of leopard and snake in Jiroft Waterfall (third millennium BC). Archaeological Research, 4, 36-37.

Rastegar Fasaei, M. (2004). Metamorphosis in mythology. Tehran: Research Institute of Humanities and Cultural Studies.

Safa, Z. (2008). Epic writing in Iran from the oldest historical era to the fourteenth century AH. Tehran: Ferdows.

Sarkarati, B. (1999). Hunted shadows. Tehran: Qatreh Publishing.

Seddiqiyan, M. (1996). Mythological-epic culture of Iran according to post-Islamic resources (Vol. I, Pishdadian). Tehran: Research Institute of Humanities and Cultural Studies.

Tusi, M. (2003). Ajā'ib al-Makhlūqāt wa Gharā'ib al-Mawjūdāt. With the effort of M. Sotoudeh. Tehran: Scientific and Cultural Publishing Company, Second Edition. 